Infusionstherapie 1981;8:211

\title{
Inhalt, Vol. 8, No. 5, 1981
}

\section{Contents}

Impressum 213

Nuutinen, L. S.; Ryhänen, P.; Pihlajaniemi, R.; Holl-

mén, A. und Tyrväinen, L., OululFinnland

Zink-, Kupfer-, Kalzium- und Magnesium-Anteil im

Serum und im Urin nach Herzklappenersatz 214

Malchow, H. und Horbach, L. , Tubingen/Erlangen

Kohlenhydratinfusion bei internistischen Erkrankungen.

Eine vergleichende Studie bei stoffwechselgesunden, leberkranken und diabetischen Patienten

II. Zielsetzung, Durchführung und Statistik der Versuche zur Langzeitinfusion von Kohlenhydratlösungen 218

Knoche, E.; Biebl, A. und Dick, W., Ulm

Der Einfluß der präoperativen Nahrungs- und Flüssigkeitskarenz auf verschiedene metabolische Parameter bei geriatrischen Patienten 224

Hinweise für Autoren 232

Fuchs, H.-H.; Brandl, M. und Arnold, K., Erlangen Parenterale und enterale Ernährung krisengefährdeter neurologischer Patienten unter dem Aspekt der LangzeitIntensivtherapie 234

Schmitz, J. E.; Dölp, R.; Grünert, A.

und Ahnefeld, F.W., Ulm ,

Verhalten der freien Aminosäuren im Plasma und im Urin polytraumatisierter Intensivpatienten unter Zufuhr einer Aminosäurenlösung mit 10\%igem Gehalt verzweigtkettiger Aminosäuren 244

Koerner, K.; Stampe, D. und Kubanek, B., Ulm

Das tiefgefrorene Frischplasma in der Blutkomponententherapie: Herstellung - Qualitätskontrolle - Indikation 253

Buchbesprechung 260

Sonderhefte/Sonderbände $\quad 260$ Imprint 213

Nuutinen, L.S.; Ryhänen, P.; Pihlajaniemi, R.; Holl-mén,A. and Tyrväinen, L., Oulul Finland The Levels of Zinc, Copper, Calcium and Magnesium in Serum and Urine after Heart-Valve Replacement .... 214

Malchow, H. and Horbach, L., Tubingen/Erlangen

Carbohydrate Infusion in Internal Diseases. 
A Comparative Study in Patients with Liver Cirrhosis,

Diabetes and a Control Group.

II. Problems, Methods and Statistics 218

Knoche, E.; Biebl, A. and Dick, W., Ulm

The Influence of Pre-Operative Food and Fluid Restric

tion on Various Metabolic Parameters in Geriatric

Patients 224

Instructions for Authors 232

Fuchs, H.-H.; Brandl, M. and Arnold, K., Erlangen

Parenteral and Enteral Nutrition of Neurological Patients

in Critical Conditions Regarding Long-Term Intensive-

Therapy 234

Schmitz, J. E.; Dölp, R.; Grünert, A. and Ahnefeld, F. W., Ulm

Investigations on Free Amino Acid Concentration in

Plasma and Urine of Severely Traumatized Intensive

Care Patients Receiving an Amino Acid Solution Con

taining $10 \%$ of Branched Chain Amino Acids

Koerner, K.; Stampe, D. and Kubanek, B., Ulm

Fresh Frozen Plasma in Blood-Component Therapy: Pre

paration - Quality Control - Indication 253

Book Review 260

Special Editions 260

Bibliographischer Hinweis: Inhaltsverzeichnisse dieser Zeitschrift erscheinen regelmäßig in Current Content ${ }^{\wedge}$ sowie in anderen bibliographischen Diensten. 